\title{
Pelaksanaan Pendidikan Karakter Dalam Pembelajaran Pendidikan Agama Islam di SMP Negeri 1 Palupuh
}

\author{
Yopie Andi Restari ${ }^{1}$, Rini Rahman ${ }^{2}$ \\ yopieandirestari@10gmail.com ${ }^{1}$, rinirahman@fis.unp.ac.id ${ }^{2}$ \\ Universitas Negeri Padang, Indonesia ${ }^{1,2}$
}

\begin{tabular}{l}
\hline ARTICLE INFO \\
\hline Article history: \\
Received 5 Agustus 2021 \\
Revised 24 Agustus 2021 \\
Accepted $31 \quad$ Agustus \\
2021 \\
\hline Keywords: \\
Pelaksanaan, Pendidikan \\
Karakter, Pembelajaran \\
PAI
\end{tabular}

Clonflict of Interest:

None

\section{Funding:}

None

\begin{abstract}
ABSTRAK
Penelitian ini dilakukan untuk mengetahui Pelaksanaan pendidikan karakter dalam pembelajaran PAI (Pendidikan Agama Islam). Penelitian ini menggunakan pendekaatan deskriptif kualitatif. Data diperoleh melalui wawancara, observasi, dan dokumentasi. Data analisis melalui tida tahap yaitu reduksi data, penyajian data, dan penarikan kesimpulan. Penelitian ini menemukan poin utama yaitu pelaksanaan pendidikan karakter dilaksanakan melalui 2 tahap yaitu tahap perencanaan dan tahap pelaksanaan. Dalam tahap perencanaan pembelajaran yang di lakukan oleh guru PAI yaitu merancang RPP dari kelas VII. Perancangan RPP yang telah ditambah dengan poin pendidikan karakter religius, karakter disiplin, karakter tanggung jawab dan karakter mandiri. Kemudian dalam tahap pelaksaaan pembelajaran guru mengaplikasikan RPP yang telah dirancang sekaligus menanamkan nilai karakter religius, karater disiplin, karakter tanggung jawab dan karakter mandiri.
\end{abstract}

Corresponding Author: Yopie Andi Restari, Department Islamic Education, Faculty of Social Science, Universitas Negeri Padang, Indonesia, Email: yopieandirestari@10gmail.com Phone: +62812-677-26347

(c) $\underset{\mathrm{EY}}{(\mathbf{9}}$ Copyright $\odot 2021$, Author(s)

\section{Pendahuluan}

Tantangan pendidikan saat ini untuk menghasilkan SDM (Sumber Daya Manusia) yang berkualitas dan tangguh semakin berat.Apalagi dalam kondisi pandemi Covid-19 yang mengharuskan kegiatan proses pendidikan dilakukan secara Daring (Dalam Jaringan). Dimana proses pembelajaran ini hanya mengandalkan 
aplikasi-aplikasi dan media yang terdapat di gadget peserta didik.Sehingga guru tidak bisa memantau kegiatan yang dilakukan peserta didik selama proses pembelajaran. Dalam hal ini tujuan pendidikan nasional tidak berjalan dengan semestinya.Karena pendidikan mempunyai peran penting dalam membangun kecerdasan sekaligus kepribadian peserta didik menjadi lebih baik.Oleh karena itu, pendidikan secara terus menerus dibangun dan dikembangkan agar dari proses pelaksanaanya menghasilkan generasi yang diharapkan. Dalam rangka menghasilkan peserta didik yang unggul maka proses juga senantiasa di evaluasi dan diperbaiki. Salah satu upaya perbaikan kualitas pendidikan adalah melalui pendidika karakter.

Pendidikan karakter (character education) dalam konteks sekarang sangat relevan untuk mengatasi krisis moral yang sedang melanda di negara kita.Krisis tersebut antara lain berupa kurang menghargai guru, kurangnya sopan santun terhadap yang lebih tua maupun teman sebaya serta kebiasaan menyontek, sudah menjadi masalah sosial hingga saat ini yang belum dapat diatasi secara tuntas. Demoralisasi terjadi karena proses pembelajaran cenderung mengajarkan pendidikan moral dan budi pekerti sebatas teks dan kurang mempersiapkan peserta didik untuk menyikapi dan menghadapi kehidupan kontradiktif.Selain itu, pendidikan agama yang selama puluhan tahun dianggap sebagai salah satu media efektif dalam penginternalisasikan karakter luhur terhadap peserta didik, dalam kenyataannya hanya sekedar mengajarkan dasar-dasar agama ( Wibowo, 2012:55).Bahkan semakin kehilangan perannya sebagai media yang mengantarkan peserta didiknya untuk memahami dan mengamalkan ajaran agamanya.

Dalam konteks pendidikan formal di sekolah, bisa jadi salah satu penyebabnya karena pendidikan di Indonesia lebih menitik beratkan kepada pengembangan intelektual atau kognitif semata, sedangkan aspek soft skill atau non akademik sebagai unsur utama pendidikan moral belum diperhatikan. Padahal, pencapaian hasil belajar peserta didik tidak dapat hanya dilihat dari ranah kognitif dan psikomotorik, sebagaimana selama ini terjadi dalam praktik pendidikan kita, tetapi harus juga dilihat dari hasil afektif.

Berdasarkan kenyataan sebagaimana diuraikan, maka sudah saatnya pendidikan yang berbasis hard skill, harus mulai dibenahi.Dengan kata lain, selain berbasis hard skill. Pembelajaran juga harus dibarengi dengan basis pengembangan soft skill.Hal ini menjadi penting kaitannya dengan dalam pembentukan karakter anak bangsa sehingga selain mereka mampu bersaing, juga beretika, bermoral, sopan santun dan berinteraksi dengan masyarakat.

\section{Tinjauan Pustaka}

\section{A. Pendidikan Karakter}

\section{1) Pengertian Pendidikan Karakter}

Pendidikan karakter menurut Citra (2012:238), suatu sistem penanaman nilainilai karakter kepada warga sekolah yang meliputi komponen pengetahuan, kesadaran atau kemauan, dan tindakan untuk melaksanakan nilai-nilai tersebut, baik 
terhadap Tuhan Yang Maha Esa (YME), diri sendiri, sesama, lingkungan, maupun kebangsaan sehingga menjadi manusia insan kamil. Selanjutnya, pendidikan karakter adalah proses pendidikan secara holistic yang menghubungkan dimensi moral dengan ranah peserta didik sebagai pondasi bagi terbentuknya generasi yang berkualitas yang mampu hidup mandiri dan memiliki prinsip suatu kebenaran yang dapat dipertanggung jawabkan (Raharjo, 2010:233).

Berdasarkan beberapa pendapat di atas, maka dapat dipahami bahwa pengertian pendidikan karakter adalah suatu sistem pembinaan dan penanaman nilai-nilai karakter kepada peserta didik dan warga sekolah yang mencakupi komponen pengetahuan, kesadaran atau kemauan dan tindakan untuk melaksanakan nilai-nilai tersebut.

\section{2) Tujuan Pendidikan Karakter}

Samani dan Hariyanto (2011: 42-43) mendefinisikan Pendidikan karakter memiliki tujuan dalam menanamankan nilai dalam diri peserta didik dan pembaruan tata kehidupan bersama yang lebih menghargai kebebasan individu. Tidak hanya itu, pendidikan karakter bertujuan menambahkan mutu penyelenggaraan dan hasil pendidikan di sekolah yang bertujuan pada pencapaian pembentukan karakter dan akhlak mulia peserta didik secara utuh, terpadu, dan seimbang sesuai dengan standar kompetensi lulusan.

Sedangkan menurut Hasan (2010:7) menjelaskan tujuan pendidikan karakter sebagai berikut.

a) Menumbuhkan potensial kalbu/nurani/ afektif peserta didik sebagai manusia dan warga negara yang mempunyai nilai-nilai budaya dan karakter bangsa.

b) Menumbuhkan kebiasaan dan sikap peserta didik yang terpuji dan seiring dengan nilai-nilai global dan kebiasaan budaya bangsa yang religius.

c) Menanamkan jiwa kepemimpinan dan tanggung jawab peserta didik menjadi generasi penerus bangsa.

d) Menumbuhkan keahlian peserta didik menjadi orang yang mandiri, kreatif, berwawasan kebangsaan.

Mengembangkan kawasan kehidupan sekolah sebagai kawasan belajar yang aman, jujur, penuh kreativitas dan persahabatan, serta dengan rasa kebangsaan yang tinggi dan penuh kekuatan. Berdasarkan penjelasan di atas, maka dapat dipahami bahwa tujuan pendidikan karakter adalah membentuk, menanamkan, memfasilitasi, dan mengembangkan nilai-nilai positif pada peserta didik sehingga menjadi pribadi yang unggul dan bermartabat serta berakhlakul karimah.

\section{3) Prinsip-prinsip Pendidikan Karakter}

Menurut Gunawan (2014:35-36), Kemendiknas merekomendasikan 11 prinsip ketika melaksanakan pendidikan karakter sebagai berikut :

a) Menawarkan nilai-nilai dasar etika sebagai basis karakter.

b) Mengidentifikasi karakter secara komprehensif agar mencakup dalam pemikiran, perasaan, dan perilaku. 
c) Memerlukan strategi yang tajam, proaktif dan efektif untuk membentuk karakter.

d) Mewujudkan komunitas sekolah yang mempunyai kepedulian.

e) Memberikan waktu kepada peserta didik untuk menunjukkan perilaku yang baik.

f) Mempunyai jangkauan atas kurikulum yang berarti dan menantang yang memperkirakan seluruh peserta didik, meningkatkan karakter mereka, dan mendukung mereka menjadi sukses.

g) Mengarahkan tumbuhnya motivasi diri pada para peserta didik

h) Mengaktifkan semua staf sekolah selaku komunitas moral yang memberi tanggung jawab untuk pendidikan karakter dan tetap pada nilai dasar yang sama.

i) Adanya penguraian kepemimpinan moral dan bantuan luas dalam meningkatkan gagasan pendidikan karakter. Mengevaluasi karakter sekolah, tugas staf sekolah selaku guru-guru karakter dan melaksanakan karakter positif pada kehidupan peserta didik.

Menurut Fathurrohman (2013:94-95), prinsip-prinsip yang dimanfaatkan ketika pengembangan pendidikan karakter sebagai berikut:

a) Berkelanjutan, mempunyai arti bahwa proses meningkatkan nilai-nilai karakter adalah sebuah proses panjang diawali dari peserta didik masuk hingga selesai dari satuan pendidikan.

b) Semua mata pelajaran, pengembangan diri, dan budaya satuan pendidikan, mewajibkan yaitu proses pengembangan karakter dilaksanakan lewat semua mata pelajaran dari setiap kulikuler, ekstrakulikuler dan kokulikuler.

c) Nilai tidak hanya diajarkan tetapi dikembangkan dengan proses belajar.

d) Proses pendidikan dilaksankan peserta didik secara bersungguh-sungguh dan menarik, prinsip ini juga menjelaskan bahwa proses pendidikan karakter dilaksankan bagi peserta didik bukan pendidik.

Berdasarkan dari beberapa pendapat di atas maka dapat disimpulkan bahwa prinsip utama dari pendidikan karakter adalah mempromosikan nilai-nilai kode etik yang berlandaskan pemikiran positif, sehingga dapat menciptakan komunitas sekolah yang penuh dengan kepedulian.

\section{4) Nilai-nilai Pendidikan Karakter}

Menurut Hasan (2010:9-10), nilai-nilai yang ditingkatkan terhadap pendidikan karakter dirumuskan sebanyak 18 nilai karakter sebagai berikut :

a) Religius, yaitu sikap dan perilaku yang ikut serta dalam ajaran agama yang dianutnya, toleran kepada pelaksanaan ibadah agama lain, dan hidup rukun dengan pemeluk agama lain.

b) Jujur, yaitu sikap yang dilandaskan pada usaha membentuk dirinya selaku orang yang tetap dapat dipercaya terhadap perkataan, tindakan dan pekerjaan. 
Yopie Andi Restari dan Rini Rahman: Pelaksanaan Pendidikan Karakter Dalam Pembelajaran...

c) Toleransi, yaitu sikap dan perilaku yang menghargai perbedaan agama, suku, etnis,pendapat, sikap, dan perilaku orang lain yang berlainan dari dirinya.

d) Disiplin, yaitu perilaku yang menentukan perilaku tertib dan patuh pada beragam ketetapan dan peraturan.

e) Kerja keras, yaitu perilaku yang menentukan usaha sungguh-sungguh dalam menyelesaikan berbagai hambatan belajar beserta mengerjakan tugas dengan sebaik-baiknya.

f) Kreatif,yaitu berpikir dan melaksanakan sesuatu untuk melahirkan cara atau hasil baru dari sesuatu yang telah dimiliki.

g) Mandiri, yaitu sikap dan watak yang tidak gampang bergantung pada orang lain ketika menyelesaikan tugas-tugas.

h) Demokratis, yaitu usaha berfikir, bersikap, dan bekerja yang menimbang sama hak dan kewajiban dirinya dan orang lain.

i) Rasa ingin tahu, yaitu sikap dan perbuatan yang selalu berusaha untuk memahami lebih menyeluruh dan meluas dari sesuatu yang dipelajarinya, dilihat, dan didengar.

j) Semangat kebangsaan, yaitu cara berpikir, bertingkah, dan berpengetahuan yang mencantumkan keperluan bangsa dan negara di atas keperluan diri sendiri dan kelompok.

k) Cinta tanah air, yaitu usaha berfikir, berperilaku, dan bertindak yang menentukan ketaatan, perhatian, dan penghargaan yang tinggi tentang bahasa, lingkungan fisik, sosial, budaya, ekonomi, dan politik bangsa.

1) Menghargai prestasi, yaitu perilaku dan sikap yang memotivasi dirinya untuk memperoleh sesuatu yang bermanfaat terhadap masyarakat, dan mempertimbangkan, serta menghormati keberhasilan orang lain.

m) Bersahabat/komunikatif, yaitu perbuatan yang menunjukkan rasa bahagia berbicara, bersosialisasi, dan bekerja sama dengan orang lain.

n) Cinta damai, yaitu sikap, ucapan, dan perilaku yang menghasilkan orang lain merasa bahagia dan nyaman atas kehadiran dirinya.

o) Gemar membaca, yaitu terbiasa meluangkan waktu untuk membaca beragam bacaan yang memberikan kebaikan bagi dirinya.

p) Peduli lingkungan, yaitu perilaku dan tindakan yang tetap berusaha menahan kerusakan terhadap lingkungan alam di sekitarnya, dan meningkatkan usahausaha untuk memperbaharui kerusakan alam yang sudah terjadi.

q) Peduli sosial, yaitu perilaku dan tindakan yang tetap ingin memberikan pertolongan kepada orang lain dan masyarakat yang membutuhkan.

r) Tanggung jawab, yaitu sikap dan tindakan seseorang untuk melakukan tugas dan kewajibannya, yang memang harus dia lakukan, kepada diri sendiri, masyarakat, lingkungan (alam, sosial dan budaya), negara dan Tuhan Yang Maha Esa.

\section{5) Implementasi Pendidikan Karakter}

\section{a. Pengertian Implementasi}


Implementasi adalah bermuara pada aktivitas, aksi, tindakan atau adanya mekanisme suatu sistem, implemantasi bukan sekedar aktivitas, tapi suatu kegiatan yang terencana dan untuk mencapai tujuan kegiatan (Usman, 2002: 70). Sedangkan pendidikan karakter merupakan usaha penanaman nilai-nilai karakter kepada peserta didik agar menjadi generasi muda yang beretika, bertanggung jawab, dan peduli.Maka dapat disimpulkan bahwa implementasi pendidikan karakter yaitu suatu aktivitas dan tindakan yang dilakukan pendidik melalui penanaman nilai-nilai karakter kepada peserta didik agar menjadi manusia yang berakhlak mulia.

\section{b. Langkah-langkah Implementasi Pendidikan Karakter}

a) Menurut Judian (2010:285-286), Dalam pelaksanaan pendidikan karakter dapat melalui beberapa langkah-langkah yang meliputi :Pengintegrasian dalam mata pelajaran. Pengembangan nilai-nilai pendidikan karakater bangsa mengkombinasi pada semua pokok bahasan dari setiap mata pelajaran. Nilai-nilai tersebut dipadukan dalam silabus dan RPP. Pengembangan nilai-nilai itu dalam silabus ditempuh melalui cara-cara: mengkaji Standar Komptensi (SK) dan Kompetensi Dasar (KD) pada Standar Isi (SI) untuk menetapkan apakah nilai-nilai karakter bangsa yang ditetapkan itu sudah tercakup di dalamnya.

b) memerlukan tabel 1 yang menunjukkan keterkaitan antara SK dan KD terhadap nilai dan indikator untuk menetapkan nilai yang akan dikembangkan.

c) memasukkan nilai-nilai budaya dan karakter bangsa dalam tabel 1 ke pada silabus.

d) mencantumkan nilai-nilai yang telah ada dalam silabus ke dalam RPP.

e) mengembangkan proses pembelajaran peserta didik secara aktif yang menguatkan peserta didik mempunyai waktu untuk melakukan penghayatan nilai dan membuktikannya terhadap perilaku yang sesuai

f) memberikan pertolongan kepada peserta didik, baik yang menghadapi kesusahan untuk menghayati nilai maupun untuk membuktikannya terhadap perilaku.

\section{B. Pembelajaran Pendidikan Agama Islam}

\section{Pengertian Pembelajaran Pendidikan Agama Islam}

Menurut Umar dan Ismail (2020:2), pengertian Pendidikan Agama Islam merupakan suatu program pendidikan yang berupaya untuk menanamkan nilai-nilai melalui proses pendidikan dan pembinaan. Sedangkan menurut Muhaimin (2007:6), bahwa Pendidikan Agama Islam bermakna upaya mendidik agama islam atau ajaran islam dan nilai-nilainya agar menjadi pandangan dan sikap hidup seseorang. Dari aktivitas mendidikkan agama islam itu bertujuan untuk membantu seseorang atau 
sekelompok anak didik dalam menanamkan dan menumbuhkembangkan ajaran islam dan nilai-nilainya untuk dijadikan sebagai pandangan hidup.

Dari beberapa pendapat pendapat di atas, sehingga dapat ditarik kesimpulan bahwa pembelajaran pendidikan agama Islam merupakan usaha menanamkan nilainilai Islam melalui pengajaran, bimbingan, dan latihan yang dilaksanakan secara sadar dan penuh tanggungjawab dalam rangka menjalankan ibadah kepada Allah SWT agar mencapai kebahagiaan di dunia dan akhirat.

\section{Karakteristik Pembelajaran Pendidikan Agama Islam}

Setiap mata pelajaran mestinya mempunyai sifat khas atau karakteristik tertentu yang membedakan dengan mata pelajaran lain, begitu juga dengan PAI. Memiliki sifat khas ataupun karakteristik mata pelajaran PAI dapat di uraikan sebagai berikut ;

a. PAI adalah turunan mata pelajaran yang dibesarkan dari ajaran-ajaran pokok (dasar) yang terletak dalam agama Islam juga merupakan mata pelajaran pokok yang tidak bisa diuraikan dari ajaran Islam melalui tujuan mengembangkan akhlak dan karakter peserta didik.

b. Tujuan PAI yaitu terwujudnya peserta didik yang beriman dan bertaqwa kepada Allah SWT, berbudi pekerti yang luhur (berakhlak mulia), mempunyai wawasan mengenai ajaran pokok Agama Islam dan melaksanakannya terhadap kehidupan sehari-hari, juga mempunyai wawasan yang matang dan mendalam mengenai Islam kemudian dapat memadai baik bagi kehidupan bermasyara tidak hanya itu bermanfaat juga untuk meneruskan pendidikan ke jenjang yang lebih tinggi.

c. Pendidikan Agama Islam merupakan suatu program pembelajaran, membimbing kepada meliputi memimbing aqidah dan ketaqwaan peserta didik, untuk membentuk peserta didik agar lebih rajin mempelajari ilmu-ilmu lain yang di berikan oleh pihak sekolah, menggerakkan peserta didik untuk menjadi kritis, cerdas dan kreatif, sebagai tumpuan dalam berperilaku kehidupan sehari-hari di masyarakat.

d. Pembelajaran PAI tidak saja menitik beratkan aspek kognitif, melainkan juga efektif dan psikomotoriknya.

e. Isi mata pelajaran PAI dilandaskan dan dikembangkan dari ketetapanketetapan yang terdapat dalam dua sumber pokok ajaran agama islam, yaitu Al-Qur'an dan sunnah nabi Muhammad SAW (dalil naqli) dan selanjutnya diperbanyak dengan hasil-hasil istinbath atau ijtihad (dalil aqli) para ulama yang lebih rinci dan terurai.

f. Materi PAI dibesarkan dari tiga kerangka dasar ajaran Islam, meliputi gagasan iman, syari'ah dari gagasan Islam, dan akhlak dari gagasan ihsan. Dari ketiga konsep dasar itulah berkembang menjadi beragam tinjauan keIslaman, termasuk tinjauan-tinjauan yang berhubungan dengan ilmu, tekhnologi, seni dan budaya. 
g. Output program pembelajaran PAI di sekolahan yaitu terwujudnya peserta didik yang mempunyai akhlak mulia (budi pekerti yang luhur) yang pada dasarnya memiliki misi utama diutusnya Nabi Muhammad SAW di dunia ini.Pendidikan akhlak merupakan jiwa pendidikan terhadap Islam, kemudian perolehan akhlak mulia (karimah) merupakan wujud seharusnya dari pendidikan.Bila dihubungkan dengan hubungan pembelajaran yang lainnya, sehingga harus ditegaskan dalam pembelajaran PAI tidak serupa dengan pendidikan jasmani dan pendidikan akal.Eksistensi program pembelajaran yang lain juga menjadi keperluan bagi para peserta didik yang tidak dapat diabaikan. Maka dalam pencapaian akhlak mulia dibutuhkan tanggung jawab dari seluruh bidang termasuk pembelajaran non-PAI dan pendidik lainnya.Jadi, meskipun akhlak itu terlihat hanya menjadi muatan pembelajaran PAI, akan tetapi pembelajaran lain juga butuh mengandung muatan akhlak. Tidak itu, seluruh pendidik harus mengawasi akhlak peserta didik dan berusaha menyampaikan dalam setiap proses pembelajaran.Akhirnya, perolehan dari akhlak mulia tidak cukup hanya lewat pembelajaran PAI (Nazarudin, 2007:13-15).

\section{Fungsi Pembelajaran Pendidikan Agama Islam}

Pendidikan agama Islam dalam prosesnya mempunyai kewajiban yang sangat penting, yaitu sebagai penanaman keimanan dan ketaqwaan terhadap diri seseorang. Tidak hanya itu, pendidikan agama Islam juga mempunyai fungsi yang terdapat dalam pendidikan (Majid, 2005:134-135), diantaranya :

a. Pengembangan, yaitu menumbuhkan keimanan dan ketaqwaan peserta didik kepada Allah SWT; yang sudah ditanamkan terhadap lingkungan keluarga. Pada mulanya upaya dalam menanamkan keimanan dan ketaqwaan tersebut merupakan tanggung jawab seluruh orangtua dalam keluarga. Sekolah berfungsi sebagai tempat menumbuh kembangkan kemampuan yang terdapat pada diri anak lewat bimbingan, pengajaran dan pelatihan sehingga keimanan tersebut dapat tumbuh secara maksimal dan setara dengan tingkat perkembangannya.

b. Penanaman nilai, yaitu memberikan instruktur dalam hidup agar mendapatkan kebahagiaan hidup di dunia dan akhirat.

c. Penyesuaian mental, merupakan kegiatan menyesuaikan diri terhadap lingkungannya, baik lingkungan fisik maupun sosial juga dapat mengganti lingkungannya sesuai dengan ajaran agama Islam.

d. Perbaikan, merupakan perbaikan kesalahan, kekurangan dan kelemahan peserta didik terhadap akidah, pengetahuan, serta pengamalan ajaran Islam dalam kehidupan sehari-hari yang awalnya mungkin mereka dapatkan lewat sumber-sumber yang ada di lingkungan keluarga dan masyarakat. 
Yopie Andi Restari dan Rini Rahman: Pelaksanaan Pendidikan Karakter Dalam Pembelajaran...

e. Pencegahan, merupakan penangkal hal-hal negatif dari lingkungan peserta didik atau dari budaya lain yang mampu membahayakan dirinya dan menghentikan perkembangan menuju manusia seutuhnya.

f. Pengajaran mengenai ilmu pengetahuan keagamaan secara umum (alam nyata) dan (nir-nyata), sistem dan fungsionalnya.

g. Penyaluran, yaitu sebagai menyalurkan peserta didik yang mempunyai bakat khusus di bidang agama sehingga bakat tersebut berhasil berkembang secara maksimal kemudian dapat digunakan untuk dirinya sendiri dan orang lain.

\section{Implementasi Pendidikan Karakter dalam Pembelajaran Pendidikan Agama Islam}

Pada pelaksanaannya, proses pembelajaran pada mata pelajaran melalui tiga tahapan yaitu perencanaan, pelaksanaan, dan evaluasi.

Perencanaan pembelajaran merupakan sesuatu hal yang penting bagi guru dalam menjalankan tugasnya. Perencanaan pembelajaran adalah proyeksi tentang sesuatu yang dilakukan oleh guru dalam proses belajar mengajar.Pembelajaran akan lebih optimal jika guru terlebih dahulu menyiapkan perencanaan pembelajaran.perencanaan pembelajaran perlu dilakukan oleh guru untuk mengkoordinasikan komponen-komponen pembelajaran. Perencanaan pembelajaran berbasis karakter berarti menyusun rencana pembelajaran yang lebih mengedepankan aspek sikap, perilaku karakter yang akan diinternalisasikan ke dalam diri peserta didik (Nadzir, 2013:339).

Pada tahap perencanaan, bagian penting yang hendaknya dilaksankan pendidik yaitu menguraikan Standar Kompetensi (SK) atau Kompetensi Dasar (KD), pengembangan silabus, penyusunan RPP, dan penyiapan bahan ajar. Menguraiakan SK atau KD dilaksanakan sebagai tujuan untuk mendapatkan nilainilai karakter yang secara esensi dapat dikombinasi pada SK atau KD yang saling bertautan. Hendaknya dicatat hingga pemahaman nilai-nilai karakter ini tidak dirancang untuk memilih nilai karakter yang mampu dikembangkan terhadap pembelajaran SK atau KD yang bersangkutan.

Pelaksanaan Pembelajaran PAI ialah pelaksanaan dari RPP. Dalam pelaksanaan pembelajaran ada beberapa kegiatan yang perlu dilihat diantaranya : kegiatan pendahuluan, kegiatan inti dan kegiatan penutup (Permendiknas 2007) Pendahuluan meliputi kegiatan pendahuluan, pendidik hendaknya cakap dalam mempersiapkan dan mengkondisikan peserta didik dalam mengikuti proses pembelajaran, menautkan wawasan sebelumnya terhadap materi yang akan dipelajarai, dan juga menjelaskan tujuan pembelajaran.

Bagian inti dibagi atas tiga tahap, yaitu eksplorasi, elaborasi, dan konfirmasi. Pada tahap eksplorasi, peserta didik diberikan sarana untuk mendapatkan pengetahuan. Pada tahap elaborasi, peserta didik melaksanakan bermacam kegiatan pembelajaran supaya pengetahuan yang dipunyai berkembang ke arah penguasaan, keterampilan, dan sikap dari pengetahuan yang sudah dipunyai. Maka pengetahuan, keterampilan, serta sikap yang dimilikinya berkembang lebih 
mendalam dan lebih luas. Dan pada tahap takhir, yaitu tahap konfirmasi, peserta didik mendapatkan umpan balik atas keabsahan dan kelayakan dari pengetahuan, keterampilan, dan sikap yang didapat pada saat pembelajaran berlangsung.

Terakhir yaitu penutup dimana peserta didik mendapatkan kesimpulan dari hasil pengetahuan, keterampilan dan sikap yang didapatkan dan melaksankan refleksi untuk mendapatkan pengalaman belajar yang sudah dilaksankan.

\section{Metodologi}

Metode yang digunakan dalam penelitian ini yaitu metode kualitatif dengan instrument seperti wawancara, observasi, dan dokumentasi, yang dimana data primer dari penelitian ini yaitu kepala sekolah, waka kurikulum dan pendidik PAI (Pedidikan Agama Islam) di SMP Negeri 1 Palupuh. Adapun data sekunder atau data pendukung dari penelitian ini adalah peserta didik SMP Negeri 1 Palupuh dan masyarakat di sekitar SMP Negeri 1 Palupuh.

Setelah dilakukan kegiatan wawancara, observasi dan dokumentasi maka penulis melakukan teknik analisis dalam metode penelitian kualitatif serta teknik pengabsahan data dari penelitian yang telah dilakukan yaitu penelitian mengenai "Pelaksanaan Pendidikan Karakter dalam Pemeblajaran Pendidikan Agama Islam di SMP Negeri 1 Palupuh.

\section{Hasil dan Pembahasan}

\section{A. Implementasi Pendidikan Karakter dalam Pembelajaran PAI di SMP Negeri 1 Palupuh}

Dalam mengimplementasikan pendidikan karakter pada pembelajaran pendidikan agama Islam (PAI) di sekolah, SMP Negeri 1 Palupuh mempunyai perencanaan dan pelaksanaan dalam mengembagkan nilai-nilai pendidikan karakter pada peserta didik sebagai berikut :

\section{a. Perencanaan Pembelajaran}

Perencanaan dilakukan yang pertama yaitu dari pendidik. Pendidik mempunyai peran penting dalam melaksanakan pendididikan karakter dalam pembelajaran. Perencanaan perlu dilakukan untuk menentukan keberhasilan proses suatu pembelajaran yang akan dilaksanakan, berhasil atau tidaknya suautu pembelajaran dapat dilihat bagaimana seorang pendidik merencanakannya, begitu juga dengan pendidikan karakter, jika tidak direncanakan dengan baik maka nilai-nilai yang disampaikan tidak aka bisa tercermin ke dalam tingkah laku peserta didik

Tabel 4.1 Perencanaan Pembelajaran

\begin{tabular}{rcl}
\hline No. & Informan & Petikan Wawancara \\
\hline 1. & Guru & Dalam perencanaan RPP sudah dicantumkan pendidikan \\
& Agama & karakter yang dalam penyusunannya dengan menambahkan \\
& & kolom karakter tepat disebelah indikator pencapaian belajar.
\end{tabular}


Yopie Andi Restari dan Rini Rahman: Pelaksanaan Pendidikan Karakter Dalam Pembelajaran...

\begin{tabular}{ccl}
\hline & $\begin{array}{l}\text { Pengembangan nilai karakter dalam RPP membutuhkan } \\
\text { kreatifitas dari masing-masing guru mata pelajaran dalam } \\
\text { menganalisis kompetensi dasar (KD) }\end{array}$ \\
\hline 2. & Kepala & $\begin{array}{l}\text { Perencanaan pembelajaran merupakan suatu proses } \\
\text { Sekolah } \\
\end{array}$ \\
& $\begin{array}{l}\text { kerjasama yang tidak hanya menitik beratkan pada kegiatan } \\
\text { peserta didik hendaknya secara bersama-sama berusaha } \\
\text { mencapai tujuan pembelajaran yang telah ditentukan }\end{array}$ \\
\hline
\end{tabular}

Sebelum pendidik melakukan pembelajaran hendaknya pendidik terlebih dahulu merancang rencana pelaksanaan pembelajaran atau disebut dengan RPP ( Rencana Pelaksanaan Pembelajaran). Seperti yang disampaikan oleh Bapak Rolly Ferdian Pratama selaku guru PAI mengatakan " Dalam RPP sudah dicantumkan pendidikan karakter yang dalam penyusunannya dengan menambahkan kolom karakter tepat disebelah indikator pencapaian belajar. Pengembangan nilai karakter dalam RPP membutuhkan kreatifitas dari masing-masing guru mata pelajaran dalam menganalisis kompetensi dasar (KD)”. (Wawancara Peneliti, 23 Maret 2021).

Analisis Materi SK, KD, Pendidikan Agama Islam serta Nilai-nilai Karakter

\begin{tabular}{|c|c|c|c|c|c|}
\hline MATERI & SK & KD & $\begin{array}{c}\text { Materi Penanaman } \\
\text { Nilai Karakter dalam } \\
\text { Pembelajaran }\end{array}$ & $\begin{array}{c}\text { Metode } \\
\text { Pembelaja } \\
\text { ran }\end{array}$ & $\begin{array}{l}\text { Nilai } \\
\text { Karakte } \\
\text { r }\end{array}$ \\
\hline Shalat Berjam'ah & $\begin{array}{l}\text { Memahami } \\
\text { tata cara shalat }\end{array}$ & $\begin{array}{l}1.9 \\
\text { Memahami } \\
\text { ketentuan } \\
\text { salat } \\
\text { berjama'ah }\end{array}$ & $\begin{array}{l}\text { - Memahami } \\
\text { sebuah keadaan } \\
\text { shalat } \\
\text { berjama'ah bagi } \\
\text { makmum dan } \\
\text { masbuk } \\
\text { - Memahami } \\
\text { tatacara shalat } \\
\text { berjama'ah bagi } \\
\text { makmum dan } \\
\text { masbuk } \\
\text { Berperilaku } \\
\text { yang } \\
\text { mencontohkan } \\
\text { shalat } \\
\text { berjama'ah } \\
\text { ketika menjadi } \\
\text { makmum dan } \\
\text { masbuk }\end{array}$ & $\begin{array}{l}\text { Problem } \\
\text { Based } \\
\text { Learning } \\
\\
\text { Diskusi dan } \\
\text { mencari } \\
\text { informasi }\end{array}$ & $\begin{array}{l}\text { Religius } \\
\text { Disiplin }\end{array}$ \\
\hline $\begin{array}{l}\text { Sejarah } \\
\text { perjuangan Nabi } \\
\text { Muhammad saw } \\
\text { periode Madinah }\end{array}$ & $\begin{array}{l}\text { Memahami } \\
\text { sejarah Nabi } \\
\text { Muhammad } \\
\text { saw }\end{array}$ & $\begin{array}{l}2.12 \\
\text { Meneladani } \\
\text { perjuangan } \\
\text { Nabi }\end{array}$ & $\begin{array}{l}\text { - Membaca } \\
\text { materi hijrah } \\
\text { Nabi ke } \\
\text { Madinah } \\
\end{array}$ & $\begin{array}{l}\text { Reading } \\
\text { Aloud dan } \\
\text { bergantian }\end{array}$ & $\begin{array}{l}\text { Religius } \\
\text { Disiplin } \\
\text { Tanggun } \\
\text { g jawab }\end{array}$ \\
\hline
\end{tabular}




\begin{tabular}{|c|c|c|c|c|c|c|}
\hline & & $\begin{array}{l}\text { Muhammad } \\
\text { saw periode } \\
\text { Madinah }\end{array}$ & & $\begin{array}{l}\text { Memahami } \\
\text { pentingnya } \\
\text { berbagi ilmu } \\
\text { dan } \\
\text { pengetahuan } \\
\text { Berperilaku } \\
\text { amar ma'ruf } \\
\text { nahi munkar } \\
\text { sebagai } \\
\text { perwujudan } \\
\text { dari } \\
\text { pemahaman } \\
\text { makna nilai- } \\
\text { nilai hijrah Nabi }\end{array}$ & $\begin{array}{l}\text { Diskusi dan } \\
\text { mencari } \\
\text { informasi } \\
\text { Pembiasaa } \\
\text { n dan } \\
\text { keteladana } \\
\text { n }\end{array}$ & \\
\hline Taharah & $\begin{array}{l}\text { Memahami } \\
\text { ketentuan- } \\
\text { ketentuan } \\
\text { thaharah } \\
\text { (bersuci) }\end{array}$ & $\begin{array}{l}5.1 \\
\text { Menjelaskan } \\
\text { ketentuan- } \\
\text { ketentuan } \\
\text { wudhu }\end{array}$ & & $\begin{array}{l}\text { Memahami } \\
\text { urutan dan } \\
\text { manfaat dari } \\
\text { gerakan wudhu } \\
\text { Membaca do'a } \\
\text { setelah } \\
\text { berwudhu } \\
\text { Berperilaku } \\
\text { menjaga } \\
\text { kebersihan diri } \\
\text { dan lingkungan } \\
\text { sebagai } \\
\text { cerminan dari } \\
\text { perilaku } \\
\text { thaharah }\end{array}$ & $\begin{array}{l}\text { Keteladana } \\
\text { n dan } \\
\text { Tanya } \\
\text { jawab } \\
\text { Inquiri } \\
\\
\text { Pembiasaa } \\
\text { n dan } \\
\text { keteladana } \\
\text { n }\end{array}$ & $\begin{array}{l}\text { Religius } \\
\text { Disiplin } \\
\text { Tanggun } \\
\text { g jawab }\end{array}$ \\
\hline
\end{tabular}

Dari pernyataan di atas dalam pelaksaanaan pembelajaran dikelas guru terlebih dahulu merancang RPP ( Rencana Pelaksanaan Pembelajaran).RPP sudah dicantumkan pendidikan karakter yang dalam penyusunannya dengan menambahkan kolom karakter tepat disebelah indikator pencapaian belajar. Pengembangan nilai karakter dalam RPP membutuhkan kreatifitas dari masingmasing guru mata pelajaran dalam menganalisis kompetensi dasar (KD).

\section{b. Pelaksanaan pembelajaran}

Pelaksanaan pendidikan karakter dalam pembelajaran pendidikan agama Islam di SMP Negeri 1 Palupuh sudah cukup berjalan cukup baik dan sudah mempunyai tujuan yang jelas. Menurut Bapak Tamril selaku kepala sekolah mengatakan bahwa :"Dalam proses pelaksanaan pendidikan karakter di sekolah mengembangkan nilai-nilai pendidikan karakter seperti karakter religius, karakter disiplin, karakter tanggung jawab, karakter dan karakter mandiri" )". (Wawancara Peneliti, 23 Maret 2021). Sedangkan menurut Bapak Rolly Ferdian Pratama selaku 
Yopie Andi Restari dan Rini Rahman: Pelaksanaan Pendidikan Karakter Dalam Pembelajaran...

guru PAI mengatakan bahwa : "Pelaksanaan pendidikan karakter perlu adanya kerjasama yang baik antara guru dan peserta didik sehingga dalam menanamkan nilai-nilai karakter dapat terlaksana dengan baik, yang tidak hanya dilakukan melalui proses pembelajaran akan tetapi lebih kepada sikap atau perbuatan secara nyata" )". (Wawancara Peneliti, 23 Maret 2021).

\section{Tabel 4.2 Pelaksanaan Pembelajaran}

\begin{tabular}{ccl}
\hline No. & Informan & Petikan Wawancara \\
1. & Guru & Pelaksanaan pendidikan karakter perlu adanya kerjasama \\
& Agama & yang baik antara guru dan peserta didik sehingga dalam \\
& & menanamkan nilai-nilai karakter dapat terlaksana dengan \\
& baik, yang tidak hanya dilakukan melalui proses \\
& pembelajaran akan tetapi lebih kepada sikap atau perbuatan \\
& secara nyata \\
\hline 2. & Kepala & Dalam proses pelaksanaan pendidikan karakter di sekolah \\
& Sekolah & mengembangkan nilai-nilai pendidikan karakter seperti \\
& karakter religius, karakter disiplin, karakter tanggung \\
& jawab, karakter dan karakter mandiri \\
\hline
\end{tabular}

Dari pertanyaan dia tas pelaksanan pendidikan karakter dalam pembelajaran PAI dilaksanakan lebih menekankan kepada pendidikan karakter seperti karakter religius, karakter disiplin, karakter tanggung jawab, serta karakter mandiri.

Dalam hal ini peneliti dapat menyimpulkan bahwa nilai-nilai pendidikan karakter yang dkembangkan di SMP Negeri 1 Palupuh yaitu melalui pelaksanaan karakter religius, karakter disiplin, karakter tanggung jawab, dan karakter karakter mandiri dalam pembelajaran PAI sebagai berikut:

\section{1) Penanaman Karakter Religius dalam Pembelajaran Pendidikan Agama Islam}

Adapun penanaman karakter religius dalam pembelajaran PAI di SMP Negeri 1 Palupuh seperti beriku :

Pada pertemuan pada hari Selasa jam 08:00- 09:30 WIB. Bapak Rolly Ferdian Pratama mengajar di kelas VII.1 dengan tema sholat berjamaah, beliau menerangkah tatacara shalat berjama'ah. Dalam pembelajaran ini karakter religius yang ditanamkan yakni melalui pembiasaan sholat dzuhur berjamaah di sekolah.

Pada pertemuan pada hari Rabu jam 10:30-12:00 WIB. Bapak Rolly Ferdian Pratama mengajar di kelas VII.2 dengan tema hijrah nabi Muhammad saw dan para sahabat ke Madinah. Dalam pembelajaran ini karakter religius yang ditanamkan pada peserta didik melalui keteladanan pada nilai-nilai perjuangan dakwah nabi yakni melalui perilaku amar ma'ruf nahi munkar yang senantiasa dicontohkan oleh pendidik dalam perilaku sehari-hari. Karakter religius yang ditanamkan pada tahap pendahuluan meliputi doa sebelum pembelajaran dan membaca asmaul husna. Pendidik membiasakan peserta didiknya untuk senantiasa memohon pertolongan Allah swt supaya dimudahkan dalam belajar. 
Pada pertemuan hari Senin jam 10:30-12:00 WIB. Bapak Rolly Ferdian Pratama mengajar di kelas VII.3 dengan tema taharah, beliau menerangkan tatacara berwudhu yang baik dan benar. Karakter religius dalam pembelajaran yang ditanamkan melalui pembiasaan menghafal doa harian agar supaya peserta didik terbiasa berdoa pada setiap kesempatan. Membaca dan mengartikan asmaul husna agar supaya peserta didik memiliki sifat rendah hati dengan mengenal kebesaran Tuhanya melalui bacaan asmaul husna. Membaca iqro dengan tartil dan tajwid yang benar dicontohkan oleh pendidik kemudian ditirukan oleh peserta didik agar supaya peserta didik mengetahui cara membaca al-Qur'an yang baik dan benar. Menanamkan karakter religius juga melalui perintah pendidik untuk membiasakan berwudu sebelum membaca al-qur'an.

\section{2) Penanaman Karakter Disiplin dalam Pembelajaran Pendidikan Agama Islam}

Adapun penanaman karakter disiplin dalam pembelajaran PAI di SMP Negeri 1 Palupuh seperti berikut :

Pada pertemuan hari Senin, jam 10:30-12:00 WIB. Bapak Rolly Ferdian Pratama mengajar di kelas VII.3 dengan tema taharah.Dalam pembelajaran ini karakter disiplin ditanamkan melalui memberikan hukuman pada peserta didik yang tidak memakai kelengakapan seragam dan yang tidak membawa buku, pemberian hukuman berupa membuang sampah dengan tujuan membiasakan peserta didik memiliki rasa tanggung jawab atas setiap perbuatan yang tidak disiplin.Dalam menanamkan karakter disiplin ditanamkan pula kejujuran peserta didik alasannya mengapa tidak membawa kelengkapan seragam maupun buku.

Pada pertemuan hari Rabu, jam 10:30-12:00 WIB. Bapak Rolly Ferdian Pratama mengajar di kelas VII.2 dengan materi hijrah nabi Muhammad saw. di Madinah. Dalam pembelajaran ini karakter disiplin ditanamkan melalui kegiatan membaca bergantian, peserta didik secara berurutan membaca dan meneruskan bacaan teman yang lainnya mendengarkan dengan penuh perhatian.

Pada pertemuan hari Selasa, jam 08:00-09:00 WIB. Bapak Rolly Ferdian Pratama mengajar di kelas VII.1 dengan materi sholat berjamaah, tema makmum masbuk.Dalam pembelajaran ini karakter disiplin ditanamkan melalui pembentukan kelompok diskusi hingga pada peserta didik mempraktikan sholat makmum masbuk secara urut dan tertib.Dalam perilaku sholat berjamaah peserta didik senantiasa diajarkan untuk selalu sholat diawal waktu sebagai bentuk kedisiplinan peserta didik terhadap waktu.

\section{3) Penanaman Karakter Tanggung Jawab Dalam Pembelajaran Pendidikan Agama Islam}

Adapun penanaman karakter tanggung jawab dalam pembelajaran PAI di SMP Negeri 1 Palupuh seperti berikut :

Pada pertemuan hari Rabu, jam 10:30-12:00 WIB. Bapak Rolly Ferdian Pratama mengajar di kelas VII.2 materi hijrah nabi Muhammad saw. menggunakan metode diskusi kelompok. Dalam pembelajaran ini karakter yang ditanamkan berupa tanggung jawab peserta didik untuk mengerjakan tugas yang diberikan oleh pendidik dan tanggung jawab sebagai anggota kelompok. Melalui nilai-nilai perjuangan Rasulullah peserta didik ditanamkan untuk memiliki rasa tanggung jawab menjaga dan menghormati orang lain, seperti menghargai pendapat dari temannya 
Yopie Andi Restari dan Rini Rahman: Pelaksanaan Pendidikan Karakter Dalam Pembelajaran...

Pada pertemuan hari Senin, jam 10:30-12:00 WIB. Bapak Rolly Ferdian Pratama mengajar taharah di kelas VII.3. Dalam pembelajaran ini, karakter tanggung jawab yang ditanamkan melalui membiasakan menjaga kebersihan kelas sebagai tanggung jawab warga kelas, peserta didik juga dicontohkan bertanggung jawab menjaga kebersihan tubunhnya salah satunya melalui tata cara berwudu yang baik dan benar serta memaknai setiap gerakan wudhu sebagai tanggung jawab orang Islam berwudhu dan mengerjakan sholat.

\section{4) Penanaman Karakter Mandiri dalam Pembelajaran Pendidikan Agama Islam}

Adapun penanaman karakter mandiri dalam pembelajaran PAI di SMP Negeri 1 Palupuh seperti berikut : Pada bulan ramadhan dilakukan penyetoran juz 30 pada jam 09:30-10:30 WIB. Dalam hal ini pendidik menanamkan karakter mandiri melalui menghafal ayat-ayat al-Qur'an, peserta didik harus mandiri dan serius dalam menghafal.

\section{Simpulan}

Berdasarkan paparan di atas dapat disimpulkan bahwa pelaksanaan pendidikan karakter dilaksanakan melalui 2 tahap yaitu tahap perencanaan dan tahap pelaksanaan.Dalam tahap perencanaan pembelajaran yang di lakukan oleh guru PAI yaitu merancang RPP dari kelas VII.Perancangan RPP yang telah ditambah dengan poin pendidikan karakter religius, karakter disiplin, karakter tanggung jawab dan karakter mandiri. Kemudian dalam tahap pelaksaaan pembelajaran guru mengaplikasikan RPP yang telah dirancang sekaligus menanamkan nilai karakter religius, karater disiplin, karakter tanggung jawab dan karakter mandiri.

\section{Referensi}

Agus,Wibowo.(2012).Pendidikan Karakter; Strategi Membangun Karakter Bangsa Berperadaban. Yogyakarta: Pustaka Belajar.

Dewi, Rini Sutra.(2017). Implementasi Pendidikan Karakter dalam Mata Pelajaran Pendidikan Agama Islam Kelas $X$ di SMA Sultan Mahmud Badaruddin Palembang .Skripsi. Uin Raden Fatah Palembang.

E. Mulyasa.(2005). Pendidikan Agama Islam Berbasis Kompetensi. Bandung:PT Remaja Rosdakarya.

Fathurrohman,Pupuh.(2013). Pengembangan Pendidikan Karakter. Bandung:Alfabeta. Gunawan,Heri.(2014). Pendidikan Karakter Konsep dan Implementasi. Bandung:Alfabeta.

Hasan, S. H., et al. (2010). Pengembangan Pendidikan Budaya dan Karakter Bangsa. Jakarta: Pusat Kurikulum, Badan Penelitian dan Pengembangan, Kementerian Pendidikan Nasional.

Judian,Sri.(2010). Implementasi Pendidikan Karakter di Sekolah Dasar Melalui Penguatan Pelaksanaan Kurikulum. Jurnal Pendidikan dan Kebudayaan Vol.16 Edisi Khusus III. 
M. Muhaimin.(2007). Pengembangan Kurikulum Pendidikan Agama Islam. Jakarta:Rajawali Press.

Majid,Abdul.(2014). Implementasi Kurikulum 2013 Kajian Teoritis dan Praktis.Bandung:Inters Media.

Nadzir, M. (2013). Perencanaan Pembelajaran Berbasis Karakter. Jurnal Pendidikan Agama Islam. 2(2.)

Rusman. (2017). Belajar dan pembelajaran berorientasi standar proses pendidikan Jakarta: Kencana.

Raharjo,Sabar Budi.(2010). Pendidikan Karakter sebaga Upaya Menciptakan Akhlak Mulia.Jurnal Pendidikan dan Kebudayaan.16(3).

Syarbini,Amirullah.(2012). Buku Pendidikan Karakter, Panduan Lengkap Mendidik Karakter Anak di Sekolah Madrasah, dan Rumah.Jakarta:Prima Pustaka.

Safitri,Novika Malinda.(2015). Implementasi Pendidikan Karakter Melalui Kultur Sekolah di SMP N 14 Yogyakarta. Jurnal Pendidikan Karakter. V( 2).

Samrin,S.2015. Pendidikan Agama Islam Dalam Sistem Pendidikan Nasional di Indonesia.Jurnal Al-Ta'dib. 8(1).

Samani, Muclas dan Hariyanto. (2011). Konsep danModel Pendidikan Karakter. Bandung: Remaja Rosdakarya.

Umar Mardan,Ismail Feiby.(2020).Buku Ajar Pendidikan Agama Islam (Konsep Dasar Bagi Mahasiswa Perguruan Tinggi Umum.Jawa Tengah:CV. Pena Persada.

Judian,Sri.(2010). Implementasi Pendidikan Karakter di Sekolah Dasar Melalui Penguatan Pelaksanaan Kurikulum. Jurnal Pendidikan dan Kebudayaan Vol.16 Edisi Khusus III. 